Litteratur

1. Kraemer M, Franke C, Ohmann C et al. Acute appendicitis in late adulthood: incidence, presentation, and outcome. Results of a prospective mulficenter acute abdominal pain study and a review of the literature. Langenbecks Arch Surg 2000 385: $470-81$

2. Hale DA, Jaques DP, Molloy M et al. Appendectomy. Improving care through quality improvement. Arch Surg 1997: 132: 153-7.

3. Yang HR, Wang YC, Chung PK et al. Laboratory tests in patients with acute appendicitis. ANZ Surg 2006; 76: 71-4.

4. Yang HR, Wang YC, Chung PK et al. Role of leukocyte count, neutrophil percentage, and C-reactive protein in the diagnosis of acute appendicitis in the elderly. Am Surg 2005; 71: 344-7.
5. Bugliosi TF, Meloy TD, Vukov LF. Acute abdominal pain in the elderly. Ann Emerg Med 1990; 19: 1383-6.

6. Gaitini D, Beck-Razi N, Mor-Yosef D et al. Diagnosing acute appendicitis in adults: accuracy of color Doppler sonography and MDCT compared with surgery and clinical follow-up. AJR Am J Roentgenol 2008; 190: 1300-6.

7. Strömberg C, Johansson G, Adolfsson A. Acute abdominal pain: diagnostic impact of immediate CT scanning. World J Surg 2007; 31: 2347-54.

8. Stefanidis D, Richardson WS, Chang $L$ et al. The role of diagnostic laparoscopy for acute abdominal conditions: an evidence-based review. Surg Endosc 2009: 23: 16-23.

9. Freeman BB, Critchlow JF, Cohen S et al. Spontaneous intraperitoneal hemorrhage as the initial presentation of a gastrointestinal stromal tumor: case report. Int J Emerg Med 2010; 3: 53-6. 10. Scarpa M, Bertin M, Ruffolo $C$ et al. A systematic review on the clinical diagnosis of gastrointestina stromal tumors. J Surg Oncol 2008. 98: 384-92.

11. Oncolex. Bløtvevssarkom i abdomen og bekken. www.oncolex.no/Sarkom/Diagnoser/Abdomen/ Bakgrunn/Histologi.aspx (5.7.2010).

Manuskriptet ble mottatt 17.11. 2009 og godkjent 8.7. 2010. Medisinsk redaktør Lars Frich.

\title{
Kommentar
}

\section{Spontan hemoperitoneum}

Spontan hemoperitoneum defineres som blod i peritonealhulen av ikke-traumatisk årsak. Tilstanden debuterer oftest akutt med abdominalsmerter med eller uten tegn på blødning. Blod er en svak peritoneal irritant, og smerteintensiteten er relatert til hurtighet og volum på blødningen. Diagnosen mistenkes oftest ikke før man påviser blod ved computertomografi (CT). Eventuelt påvises blod uventet ved laparoskopi eller laparotomi. I litteraturen er tilstanden beskrevet gjennom kasuistikker eller mindre pasientserier $(1,2)$.

De hyppigste årsaker til spontan hemoperitoneum er sykdomstilstander i lever, milt, blodkar eller indre genitalia hos kvinner $(1,2)$. Blødning fra lever skyldes oftest hypervaskulære svulster som hepatocellulært karsinom eller adenom, mer sjelden fokal nodulær hyperplasi, hemangiom eller levermetastase. Blødning fra milt skyldes oftest spontan ruptur som komplikasjon til infeksjon (mononukleose, malaria) eller ruptur av kongenitt miltcyste. Ektopisk svangerskap og ruptur av ovariecyste er de hyppigste gynekologiske årsakene. Ruptur av viscerale aneurismer, hyppigst miltarterieaneurismer, fulgt av nyrearterie- og leverarterieaneurismer, er ofte dramatisk (3). Risiko for ruptur av viscerale aneurismer anslås til opp mot $25 \%$, med mortalitet på $25-70 \%$ i ulike materialer (3). Aneurisme i arteria mesenterica superior og inferior er sjelden.

Et normalt blodkar kan erodere eller danne et pseudoaneurisme og gi hemoperitoneum hvis det ligger nær en inflammatorisk prosess eller tumor. Ruptur av pseudoaneurismer på grunn av pankreatitt er hyppigst. Venøs ruptur er vanligvis sekundært til intraabdominale varicer som følge av levercirrhose og portal hypertensjon. Perforert blødende ulcus eller ruptur av svulster $\mathrm{i}$ andre intraabdominale organer enn lever, milt og indre genitalia, f.eks. gastrointestinal stromal tumor eller hemangiom, er sjeldne årsaker til spontan hemoperitoneum. I enkelte tilfeller påvises ingen sikker årsak. Blødningstilstander er viktig å utelukke. Av disse er antikoagulasjon med warfarin hyppigst, men abdominalblødning assosiert med bruk av warfarin gir oftest hematom i psoas- eller rectusmuskulaturen.

CT er viktig i diagnostikken, både for å påvise blod og for å kartlegge årsaken til blødningen $(1,2)$. Blod har vanligvis høyere attenuasjon enn andre kroppsvæsker på CT, men attenuasjonen varierer avhengig av lokalisasjon, utbredelse og tid siden blødningen (2). På CT er det viktig å vurdere om det foreligger ekstravasasjon av kontrast som tegn på pågående blødning. Behandling av spontan hemoperitoneum kan være konservativ, kirurgisk eller intervensjonsradiologisk. Er pasienten hemodynamisk stabil, kan konservativ behandling og eventuelt angiografi med transarteriell embolisering vurderes. Er pasienten hemodynamisk ustabil, må pasienten få transfusjonsbehandling og mest sannsynlig akutt laparotomi. Operativ strategi vil være pakking av alle fire kvadranter i bukhulen. Systematisk utpakking starter der man antar at blødningsfokus minst sannsynlig er. Hvis lever, milt eller indre genitalia utelukkes som blødningsfokus, må man raskt avklare om det foreligger et visceralt arterieaneurisme. Den kirurgiske behandlingen vil være avhengig av årsak til blødningen og kan dreie seg om alt fra omstikning av blødende kar, reseksjon av blødende organ eller tumor, arterierekonstruksjon eller i enkelte tilfeller pakking av bukhulen, eventuelt kombinert med angiografi og transarteriell embolisering.

\section{Knut Jørgen Labori}

knab@uus.no

Avdeling for gastroenterologisk kirurgi

Oslo universitetssykehus, Ullevål

0407 Oslo

\section{Oppgitte interessekonflikter: Ingen}

\section{Litteratur}

1. Lucey BC, Varghese JC, Anderson SW et al. Spontaneous hemoperitoneum: a bloody mess. Emerg Radiol 2007: 14: 65-75

2. Mortele KJ, Cantisani V, Brown DL et al. Spontaneous intraperitoneal hemorrhage: imaging features. Radiol Clin North Am 2003; 41: $1183-201$.

3. Pasha SF, Gloviczki P, Stanson AW et al. Splanchnic artery aneurysms. Mayo Clin Proc 2007; 82: 472-9

Manuskriptet ble mottatt 10.9. 2010 og godkjent 17.9. 2010. Medisinsk redaktør Lars Frich. 